\title{
Topics In Finance Part VII—Dividend Policy
}

Judy Laux, Colorado College, USA

\begin{abstract}
This series inspects the major topics in finance, reviewing the roles of stockholder wealth maximization, the risk-return tradeoff, and agency conflicts. The current article, devoted to dividend policy, also reviews the topic as presented in textbooks and the literature.
\end{abstract}

\section{INTRODUCTION}

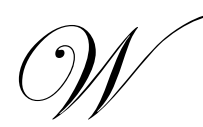

hile most current managerial finance textbooks cover the mechanics of financial management quite well, this series combats the tendency to neglect the conceptual underpinnings of that content, discussing the roles of stockholder wealth maximization, risk and return, and agency constructs. To that end, the series offers brief articles to supplement the introductory course. Hard on the heels of the topics covered to date (an introductory article providing the conceptual foundation plus financial analysis, leverage, the valuation of stocks and bonds, capital structure, and capital budgeting) [See Laux 2010 (a) through (d), as well as Laux 2011 (a) and (b).], we now look at dividend policy and address questions such as:

- Why is dividend policy important?

- What approaches to dividend policy exist?

- What theories about dividends prevail?

- What agency conflicts do financial managers face when considering dividend issuance?

- What aspects of dividend policy have researchers investigated, and what are their findings?

- What queries would lead the financial manager to make better dividend policy decisions?

In the tradition of the previous articles, we first review the mechanical/conceptual framework offered by textbooks, then investigate how risk and return and agency problems interface with stockholder wealth maximization, summarize some of the pertinent literature related to dividend policy, and conclude by helping the financial manager develop a scheme of introspection for developing the corporation's most appropriate dividend policy.

\section{DIVIDENDS IN REVIEW}

Many topics in finance invite lively conversation about whether financial managers' actions can maximize shareholder wealth, and dividend policy is no exception. Some argue that the types and amounts of dividends can, in fact, influence stock price, so let's look at those possibilities, along with some of the general tensions between managers and stockholders regarding dividend policy.

The most common type of dividend, a cash dividend represents a proportional return of cash to stockholders on a per share basis, reducing the assets and stockholders' equity (retained earnings) of the firm. While in sum this represents a shrinking of the firm, if managers are able to maintain earnings per share with the reduced asset base, the market may well view this positively. Furthermore, if dividends per share can be maintained in the foreseeable future, even greater gains may take place in the market value. This type of dividend is used when firms have sufficient retained earnings for all investments and sufficient remaining liquidity to pay cash dividends.

A second kind of dividend, the stock dividend, takes place when financial managers distribute new shares on a pro rata basis to stockholders of record. Here, no cash or other asset leaves the firm, and no "value" is 
exchanged, but if dividends per share can be maintained into the future, each owner would hold more shares (leading to more cash received in the future), and the market value per share may not drop proportionally, thereby offering a return to the shareholder, who can choose to sell shares or hold onto them for future dividends. This type of dividend is employed most often by firms with promising capital projects that require the reinvestment of retained earnings and the use of available cash for that purpose. These firms are successful in finding good projects, need to conserve cash, and are in the process of building the earnings per share base to raise cash dividends in the future.

Yet another dividend-like option available to managers is the purchase of treasury stock, whereby excess cash is used to reduce the number of shares outstanding, thus raising earnings per share and often the market price per share. Again, the asset base is reduced, but if earnings can be maintained, the market price per share should rise. All three types of dividends can be associated with a "residual approach" to dividend policy; all projects returning at least the weighted average cost of capital (discussed in Laux [2011, (b)]) are financed first, then any remaining cash (or in the absence of excess cash, new shares of stock) can be distributed to the owners.

Given these available dividend-related tools, do managers naturally have certain predispositions and, if so, do these in any way conflict with stockholder preferences? Well, yes and yes. Risk and return play their respective roles once again - dividends represent a return to shareholders, and maintaining dividends over time reduces risk in the eyes of the investor. While this sounds like a "no-brainer," consider the possible results of paying dividends. In the presence of worthy projects (positive net present value projects, using the weighted average cost of capital, WACC, as the discount rate), paying dividends might actually represent an error on the part of the financial manager. After all, investors assign managers the duty to find good projects to earn returns and make the firm grow over time (and to be better at it than the managers of similar firms). If managers are electing to pay dividends, this could signal to shareholders that projects returning at least the WACC have not been found - a negative sign, to be sure. Furthermore, it forces cash back into the hands of investors who then must find alternative investments. Still, managers should pay dividends when they run out of positive NPV projects, the residual approach to dividend policy that treats dividends as a passive variable. Whether they actually do is another thing.

While stockholders want the firm's assets to be working on their behalf (invested in good projects) or to be paid out to them (giving them liquidity, reducing risk, and allowing them to invest in other companies), managers want to retain cash for flexibility, risk reduction, special projects, power, and perquisites. They also wish to avoid having to access the capital markets (issue debt or equity) to fund projects that surface, perhaps unexpectedly. This propensity to hoard cash is considered by many to represent a major obstacle to the smooth functioning of the principal-agent relationship. To some, the resolution of this problem (referred to as the "free cash flow" problem) lies in establishing a good dividend policy. Now that we have revisited the kinds of dividends, the risk return tradeoff, some possible market reactions, and the tensions between managers and owners, we turn to the theories about dividends and whether dividend policy really matters.

\section{DIVIDEND THEORIES}

A number of academics claim unequivocally that dividends matter to stock valuation. The Gordon Growth Model [Brigham and Gordon, 1968, a true seminal article] establishes the price of a stock based in large part on dividends. Since $\mathrm{P}_{0}=\operatorname{Div}_{1} /\left(\mathrm{k}_{\mathrm{e}}-\mathrm{g}\right)$, it represents a discounted cash flow approach that sets the price of a stock today equal to the next year's expected dividend divided by the excess of the cost of equity capital over the growth rate in dividends. This model suggests that dividends don't just matter-they determine the current stock price. Furthermore, the discount rate $\mathrm{k}_{\mathrm{e}}$ is influenced by the stability of dividends and growth in them over time; the more stable these dividends (and thus their growth rate), the less risk perceived, and the lower the discount rate. Often referred to as the "bird in the hand" argument ("A bird in the hand is worth two in the bush," because cash now is better than less certain retained earnings in the future.), the resolution of uncertainty (cash in hand at the end of the period plus the promise of steady growth in dividends) is highly valued in the marketplace under this rubric.

Other theories supporting dividend relevance include signaling theory, wherein today's dividends and, more importantly, changes in them, offer information content about prospective future earnings. Because managers are reluctant to reduce an already-established dividend, if they do, it signals to the market that earnings prospects have diminished. Alternatively, when dividend increases are announced, the market interprets this as a very positive 
signal about future permanent earnings, because managers would not raise dividends if they were unsure they could maintain them into the future. The result is a "ratchet effect" - only after higher proven earnings have materialized do managers generally increase dividends, so dividends don't always adjust upward smoothly. Yet another argument favoring dividend relevance suggests that the free cash flow problem (wherein managers can abuse excess cash) can be solved by establishing appropriate dividend payment policies.

The most famous proponents of dividend irrelevance, Miller and Modigliani (M\&M) argue in their 1961 seminal work that the way a firm divides earnings between dividends and reinvestment has no impact on firm value. Higher payouts will lead to lower retained earnings and lower capital gains - it's just a trade off. Stockholders who prefer dividends will buy into firms that pay them, and those who want capital gains will buy the stocks of growth firms that reinvest earnings. This "clientele effect" generates returns to investors that align with their risk profiles, nullifying any market advantage of paying (or not paying) dividends. But in a separate article, M\&M admit to the possibility of a signaling effect, as does Lintner [1956], in another seminal article.

While neither supporting nor denying the relevance of dividend policy, the life cycle approach attempts to describe the variety of policies observed in the marketplace and changes in a firm's dividend policy over time. The life cycle theory of dividends relates dividend policy to a company's growth prospects. New companies don't have the earnings to pay dividends; growing firms want to plow back earnings into assets so don't pay cash dividends. As they become more stable, these firms pay stock dividends and some cash dividends. Stable firms pay higher cash dividends, and mature firms pay the highest dividends, because they are no longer finding an abundance of new projects requiring financing. In some ways, this represents a version of the residual approach referred to previously.

Other explanations for the variety of dividend policies and patterns include the following:

- Legal constraints-Many states require a positive balance in retained earnings before dividends can be declared.

- $\quad$ Contractual constraints-Term loans, bond indentures, preferred stock agreements, and lease contracts might include covenants limiting dividend payments.

- Owner considerations - In recognition of the clientele effect referred to above, managers might use dividend policy to ensure capital gains (by reinvesting earnings) for influential stockholders whose tax status helps them benefit from this policy.

- $\quad$ Access to capital markets - Firms with easy access to debt and equity funding can maintain higher dividend payout ratios.

- Internal constraints - Cash must be available.

Existing dividend policies include firms that follow a constant payout ratio, wherein a fixed percentage of net income is paid as dividends. The problem with this approach is that, when earnings dip, the dividend does as well, and the informational content might be bad. Other firms pay a regular dividend, a fixed dollar amount per share, which minimizes uncertainty and is often built around a "target dividend payout ratio" that is adjusted as proven higher earnings occur (leading to the ratchet effect referred to previously). Finally, other firms pay a low regular dividend plus an "extra" dividend when earnings are exceptionally high. The "extra" portion will vary, and management must be sure that this is well identified so that the information relayed is accurate, producing no unwelcome surprises.

So does dividend policy really matter? The debate continues, and we now turn to how the various arguments for and against dividend relevance are treated in the literature.

\section{DIVIDEND POLICY IN THE LITERATURE}

Researchers have been investigating dividend policy for decades, and for one of the best introductions to the literature prior to 2000, see Dividend Policy: Its Impact on Firm Value [Lease et al., 2000]. The book divides the literature into meaningful chapters, and in the final chapter, the authors confess, "...we are skeptical that a onesize-fits-all theory of dividend policy will ever gain acceptance... ...the optimal dividend policy for each firm may be unique" (p. 179). Signaling (addressing asymmetric information problems), agency costs, and taxes are foremost 
on managers' minds (p. 180). The authors suggest that, while dividend policy is important in a world of imperfect, noisy markets, it isn't as important to firm value as investment policy (p. 182), and each firm's managers must weigh how the various market frictions influence that firm's value and manage dividend policy accordingly.

In an effort to offer a more contemporary look at the dividend policy literature, the current article presents some of the most approachable works since 1990 but also refers to some of the seminal works that ask the foundational questions:

- $\quad$ Does dividend policy matter to firm value?

- $\quad$ Do changes in dividends offer predictive power about future earnings?

- $\quad$ Do dividends play an active role in containing principal-agent conflicts?

- Does dividend policy offer managers the opportunity to "misbehave"?

The selected articles fall into three categories-managerial behavior, agency theory, and information content (signaling) theory.

\section{Managerial Behavior}

Seven articles address some aspect of managerial behavior as it relates to dividend policy, with managers demonstrating human propensities, both positive and negative. Three investigations indicate that managers desire to control dividends in such a way that dividend payments do not deviate over time. Thus managers actively attempt to reduce variability (risk). Referred to as "smoothing," forcing dividends to follow a nonvolatile path resembles the "income smoothing" behavior addressed previously in this series; both earnings per share (a function of income) and dividend declaration, if made to follow a predictable path, should reduce uncertainty in the minds of investors and lead to a higher stock price. In "Dividend Policy and Financial Distress...," DeAngelo and DeAngelo [1990] find that managers will reduce dividends but react quite negatively to omitting them. Ordinarily, only in times of real distress, including losses and imposition of debt covenant restrictions, do managers completely omit dividends. Protracted financial distress leads first to a series of dividend reductions and then omissions. Similarly, in a followup article [DeAngelo, DeAngelo, and Skinner, 1992], the authors find: "An annual loss is essentially a necessary condition for dividend reductions in firms with established earnings and dividends records" (p. 1837). Garrett and Priestley [2000] suggest smoothing behavior among managers, as does Aivazian et al. [2006], who, in addition to smoothing behavior, find a higher likelihood for dividend smoothing among firms accessing public debt markets. This is not surprising, in that the scrutiny required to issue debt in public markets requires a clean record of stability, including dividend-paying experience. This represents "good behavior," albeit behavior enforced by the marketplace.

Another example of potentially good behavior provides the subject matter for Baker and Wurgler [2004] in "A Catering Theory of Dividends." Here the authors discuss a "catering" effect whereby managers respond to market demand as expressed in higher prices from those who want dividends (or who do not want them) by establishing a matching dividend payment policy. Rather than a clientele effect viewed passively by managers, here market demand is acted upon by managers. This finding suggests that managers can increase stockholder wealth by dividend policy actions, apparently constituting good behavior.

Now we turn to a couple of articles alluding to the opportunity for "bad behavior." Since one of the presumed outcomes of the principal-agent relationship is the propensity for managers to help stockholders (perhaps including themselves) at the cost of bondholders, debt issuance (with its associated covenants, which may include restrictions on dividends) represents an event worthy of investigation. The fifth article, "An Empirical Examination of Dividend Policy Following Debt Issues" [Long, Malitz, and Sefcik, 1994], suggests that managers do not use dividends to transfer wealth; that is, they do not issue debt, then turn around and increase dividends-even in the absence of restrictive covenants. The authors conclude that reputation is more important than a one-time wealth transfer. On the contrary, Francis et al. [2011] contend that managers, when protected from takeover threat, will exploit stockholders on a number of levels, reducing dividends and using the leftover cash, not "...for investments or to maximize shareholder wealth [but] to increase their own compensation and that of their employees, to reduce their firms' leverage, and to reserve the excess cash for use under their discretion" (p. 85). Bad behavior! 
Finally, as the title suggests, "Surprise! Higher Dividends = Higher Earnings Growth" [Arnott and Asness, 2003] finds the authors contradicting the widely held belief that the residual approach leads to future earnings growth. Because projects returning the cost of capital should be funded and dividends paid only in the absence of such projects, theory predicts higher future growth in earnings when managers obey this implied rule. Arnott and Asness show that "expected future earnings growth is fastest when current payout ratios are high..." and suggest that the evidence "is consistent with anecdotal tales about managers signaling their earnings expectations through dividends or engaging, at times, in inefficient empire building" (p. 70). The second part of their conclusion suggests yet another instance where managers misbehave. The first part of their conclusion provides a nice segue into the next segment on dividend literature related to agency theory, which on some levels represents the real search for managers who misbehave.

\section{Agency Theory}

Recall from our earlier discussion that a tension exists between managers who want to hold extra cash and owners who want the cash either working for them in the form of capital projects or paid out to them. Two of the key aspects of agency theory are information asymmetry (managers know more than owners) and corporate governance (in particular, structural impediments to managerial abuse or, alternatively, promotion of shareholder rights). Recall that, with dividend policy, managers control the advice given to the board to declare a dividend; managers also control the day-to-day actions related to capital investment. Thus information asymmetry naturally exists, and much of the dividend literature relates to investigating mechanisms for controlling this problem. LaPorta et al. [2000] study two agency models as they relate to dividend changes. The first, called the "outcome" theory, says that minority shareholders pressure managers to pay dividends (essentially forcing that outcome). The second, called the "substitution" theory, suggests that dividends help companies maintain access to equity markets by establishing a reputation for fair treatment of minority stockholders - dividends substitute for legal or contractual protection. The first theory supports higher payouts for firms with strong minority shareholders; the second predicts lower payouts. The authors find support for the latter. A later article by Jiraporn and Ning [2006] investigates dividend policies in firms with weak stockholder rights, finding that these firms pay higher dividends, again in support of the substitution hypothesis.

In a similar fashion, Kalcheva and Lins [2007] find that, when external shareholder protection is weak, the market rewards firms that pay dividends, resulting in higher firm values. Jiraporn and Chintrakarn [2009] discover that firms with staggered boards (an arrangement that weakens stockholders' rights and permits managerial entrenchment) have to pay dividends to offset the perceived higher agency costs associated with the side effects of staggered boards. In the extreme climate of the corporate scandals of the early 2000s, Sung et al. [2006] uncover evidence that dividend-related actions followed agency theory predictions, as firms made higher payouts concurrent with the scandals, especially in the high-tech "bubble" companies as scandals arose there. Finally, addressing the free cash flow hypothesis that supports giving cash back to stockholders to offset the propensity of managers to abuse excess cash, Grullon and Michaely [2004] investigate stock repurchases and find support for the hypothesis that using cash to buy treasury stock helps eliminate problems associated with excess cash:

We find that repurchasing firms reduce their current level of capital expenditures and research and development $(R \& D)$ expenses. Furthermore, we find that the level of cash reserves on their balance sheets significantly declines. Finally, we find that the market reaction to share repurchase announcements is stronger among those firms that are more likely to overinvest. These findings...indicate that, as implied by the free cash-flow hypothesis, firms increase their cash payouts in response to a deterioration in their investment opportunity set. (p. 652)

This work also highlights the possibility that, because the market reacts stronger to these announcements when the firm is likely to succumb to overinvestment, the event offers a signal to the market. This is the topic of the following section devoted to literature that inspects the potential information content of dividend policy.

\section{Information Content/Signaling}

The third category of articles reviewed here looks at whether dividends and changes in them can be used as a signaling device, offering investors additional information about the future earnings prospects of the firm. The 
research is decidedly mixed on this issue. Four works answer in the affirmative, two articles offer a hedged yes, and two others deny that signaling takes place. The strongest proponents of dividend signaling, Nissim and Ziv [2001] "find that dividend changes provide information about the level of profitability in subsequent years, incremental to market and accounting data. ... dividend changes are positively related to earnings changes in each of the two years after the dividend change" (p. 2111). Even this study, however, only finds significance for dividend increases, not decreases. On the contrary, in "Dividends and Losses" [1992], DeAngelo, DeAngelo, and Skinner suggest that, since losses are a necessary condition for dividend cuts, reduced dividends improve the ability of current earnings to predict future earnings. But the information content depends on the sources of losses:

...dividend reductions depend on whether earnings include unusual items that are likely to temporarily depress income. Dividend reductions are more likely given greater current losses, less negative unusual items, and more persistent earnings difficulties. Dividend policy has information content in that knowledge that a firm has reduced dividends improves the ability of current earnings to predict future earnings. (p. 1837)

Thus, even for authors who agree that dividends contain information, the predictive ability varies with the direction of dividend payments (increasing or decreasing) and accounting information sometimes does (and sometimes doesn't) receive some of the credit.

Inspecting dividend policy at the aggregate level, Wann and Long [2008] support signaling when payout ratios are above the long-run target ratios and a positive liquidity shock occurs - seems that the list of provisions necessary to defend signaling keeps getting longer, doesn't it? Tong and Miao [2011] contend that firms that pay dividends have higher quality earnings (fewer discretionary accruals, lower standard deviations, and more value relevant earnings). The same is true for firms that repurchase shares. This article is interesting, because the authors look, not at changes in dividends, but at whether dividends are being paid or not. The statistics suggest that dividend-paying firms are on firmer footing, in general, and this might constitute a "signal" to the market.

A number of articles find less support for the signaling effect. Benartzi et al. [1997] suggest that changes in dividends signal something about present earnings but not future earnings, and Garrett and Priestley [2000] agree. In his article "Are Dividend Omissions Truly the Cruelest Cut of All?" [1994], Christie discovers that dividend omissions fail to produce as large a decline in equity values as signaling and agency cost theories would predict. Liu et al. [2008] also discover an underreaction to dividend reductions and omissions. Similarly, the firms repurchasing their own shares in the 2004 Grullon and Michaely article above experienced no improvement in future profitability, although that would be an expected theoretical outcome; managers who believe their stock is undervalued in the market are likely to buy back shares, hoping that the markets will become more efficient down the road and revise their assessment upwards, at which time the managers will resell the shares in the open market. The authors offer different explanations for the positive reaction-reductions in systematic risk and the cost of capital, as well as the free cash flow explanation described previously.

Finally, among the most vehement denials of information content associated with dividend changes, Gullon et al. [2005] state that dividend changes have no signaling content about future earnings and that Nissim and Ziv [2001] misspecified their model. They also provide a quick review of some of the literature that supports their position that dividend changes offer no information about future earnings (p. 1660). Clearly, this section has demonstrated that the conversation about dividend policy is alive and well, and academics continue to pursue various strands of research. But what about what happens in practice? According to Baker and Powell [2000], financial managers' top five major determinants of dividend policy are:

- $\quad$ The level of current and expected future earnings;

- $\quad$ The pattern or continuity of past dividends;

- $\quad$ Concern about maintaining or increasing stock price;

- $\quad$ Concern that a dividend change may provide a false signal to investors;

- $\quad$ The stability of cash flows (pp. 33, 36).

So, managers seem to believe dividend policy matters - earnings support, smoothing, cash flow availability, and signaling hold high importance. The following section attempts to set forth a list of questions regarding dividend 
policy that might offer the financial manager good direction, both aiding in avoiding agency problems and possibly in helping to maximize stockholder wealth.

\section{THE BOTTOM LINE: ADVICE FOR THE FINANCIAL MANAGER}

If managers view risk and return from a different angle and are in danger of placing their own security, wealth, and power in higher esteem than that of the stockholders they are to serve, it is imperative that they remain cognizant of the temptation to make inferior dividend policy decisions. Some questions they might consider posing to themselves (and the appropriate responses) might include the following:

- Have we considered our dividend policy in tandem with our capital budgeting decisions, employing a residual approach to dividends? (yes)

- $\quad$ Has our inability to access capital markets interfered with good dividend policy? (no)

- $\quad$ To retain cash and control, have we withheld dividends to boost earnings per share by accepting profitable projects that actually return less than the weighted average cost of capital (referred to as empire building)? (no)

- $\quad$ Have we withheld dividends and used the cash for purposes that would not advance stockholder wealth maximization? (no)

- Have we engaged in unethical treasury stock transactions, benefitting some stockholders to the detriment of others? (no)

- $\quad$ Is the general nature of our dividend policy reflective of our long-run earnings capacity? (yes)

- Have we been transparent about our dividend policy and changes in it over time? (yes)

This self reflection should help managers establish and maintain a sound dividend policy in which managers view their first assignment as finding and investing in good projects and their second duty to distribute excess cash to the firm's owners. And, if uncertain about whether or not dividend policy really matters, at the very least they should employ a kind of Hippocratic Oath-above all, do no harm. Be clear about your intentions, don't run out of cash, but don't hoard it, either.

\section{THIS SERIES CONTINUES}

As with all the topics to date, the financial manager setting dividend policy holds great responsibility to weigh risk and return, share information, and make decisions that are in the long-run best interests of the stockholders. Most managers take this assignment seriously and carry it out well. The next article in the series will look at the challenges associated with mergers and acquisitions, a special case of capital budgeting and one where the literature has uncovered some evidence that financial managers are not as successful as stockholders would like.

\section{AUTHOR INFORMATION}

Judy Laux is a Gerald L. Schlessman Professor of Economics and Business at Colorado College, teaching and researching in the areas of accounting and finance. The author wishes to thank the Chapman Foundation for funding support for the current series. The author may be reached at jlaux@ coloradocollege.edu.

\section{REFERENCES}

1. Arnott, Robert D. and Clifford S. Asness. 2003. "Surprise! Higher Dividends = Higher Earnings Growth.” Financial Analysts Journal, January/February: 70-87.

2. Aivazian, Varouj A., Laurence Booth, and Sean Cleary. 2006. "Dividend Smoothing and Debt Ratings." Journal of Financial and Quantitative Analysis, Vol. 41, No. 2: 439-453.

3. Baker, H. Kent and Gary E. Powell. 2000. "Determinants of Corporate Dividend Policy: A Survey of NYSE Firms." Financial Practice and Education, Spring/Summer: 29-40.

4. Baker, Malcolm and Jeffrey Wurgler. 2004. "A Catering Theory of Dividends." The Journal of Finance, Vol. LIX, No. 3: 1125-1165.

5. Benartzi, Shlomo, Roni Michaely, and Richard Thaler. 1997. "Do Changes in Dividends Signal the Future or the Past?" The Journal of Finance, Vol. LII, No. 3: 1007-1034. 
6. Brigham, Eugene F. and Myron J. Gordon. 1968. "Leverage, Dividend Policy and the Cost of Capital." Journal of Finance, 23 (March): 85-103.

7. Christie, William G. 1994. “Are Dividend Omissions Truly the Cruelest Cut of All?” Journal of Financial and Quantitative Analysis, Vol. 29, No. 3: 459-480.

8. DeAngelo, Harry and Linda DeAngelo. 1990. "Dividend Policy and Financial Distress: An Empirical Investigation of Troubled NYSE Firms." The Journal of Finance, Vol. XLV, No. 5: 1415-1431.

9. DeAngelo, Harry, Linda DeAngelo, and Douglas J. Skinner. 1992. "Dividends and Losses." The Journal of Finance, Vol. XLVII, No 5: 1837-1863.

10. Francis, Bill B., Iftekhar Hasan, Kose John, and Liang Song. 2011. "Corporate Governance and Dividend Payout Policy: A Test Using Antitakeover Legislation.” Financial Management, Spring: 83-112.

11. Garrett, Ian and Richard Priestley. 2000. "Dividend Behavior and Dividend Signaling." Journal of Financial and Quantitative Analysis, Vol. 35, No. 2: 173-189.

12. Grullon, Gustavo and Roni Michaely. 2004. "The Information Content of Share Repurchase Programs." The Journal of Finance, Vol. LIX, No. 2: 651-680.

13. Grullon, Gustavo, Roni Michaely, Shlomo Benartzi, and Richard H. Thaler. 2005. "Dividend Changes Do Not Signal Changes in Future Profitability." Journal of Business, Vo. 78, No. 5: 1659-1682.

14. Jiraporn, Pornsit and Yixi Ning. 2006. "Dividend Policy, Shareholder Rights, and Corporate Governance." Journal of Applied Finance, Fall/Winter: 24-36.

15. and Pandej Chintrakarn. 2009. "Staggered Boards, Managerial Entrenchment, and Dividend Policy." Journal of Financial Services Research, Vol. 36: 1-19.

16. Kalcheva, Ivalina and Karl V. Lins. 2007. "International Evidence on Cash Holdings and Expected Managerial Agency Problems.” The Review of Financial Studies, Vol. 20, No 4: 1087-1112.

17. La Porta, Rafael, Florencio Lopez-de-Silanes, Andrei Shleifer, and Robert W. Vishny. 2000. "Agency Problems and Dividend Policies around the World." The Journal of Finance, Vol. LV, No. 1: 1-33.

18. Laux, Judith A. 2010. "Topics in Finance: Part I-Introduction and Stockholder Wealth Maximization." American Journal of Business Education, Vol. 3, No. 2: 15-21.

19. 2010. "Topics in Finance: Part II—Financial Analysis." American Journal of Business

Education, Vol. 3, No. 3: 81-88.

20. 2010. "Topics in Finance: Part III-Leverage." American Journal of Business

Education, Vol. 3, No. 4: 13-18.

21. 2010. "Topics in Finance: Part IV_Valuation." American Journal of Business

Education, Vol. 3, No. 9: 1-6.

22. . 2011. "Topics in Finance: Part V-Capital Structure." American Journal of Business

Education, Vol. 1, No. 1: 79-87.

23. 2011. "Topics in Finance: Part VI—Capital Budgeting." American Journal of Business Education, Vol. 4, No. 7: 29-37.

24. Lease, Ronald C., Kose John, Avner Kalay, Uri Loewenstein, and Oded H. Sarig. 2000. Dividend Policy: Its Impact on Firm Value (Boston: Harvard Business School Press).

25. Liu, Yi, Samuel H. Szewczyk, and Zaher Zantout. 2008. "Underreaction to Dividend Reductions and Omissions?" The Journal of Finance, Vol. LXIII, No. 2: 987-1020.

26. Lintner, John. 1956. "Distribution of Incomes of Corporations among Dividends, Retained Earnings, and Taxes." American Economic Review, 46: 97-113.

27. Long, Michael S., Ileen B. Malitz, and Stephan E. Sefcik. 1994. "An Empirical Examination of Dividend Policy Following Debt Issues." Journal of Financial and Quantitative Analysis, Vol. 29, No. 1: 131-144.

28. Miller, Merton and Franco Modigliani. 1961. "Dividend Policy, Growth, and the Valuation of Shares." The Journal of Finance, 34: 411-433.

29. Nissim, Doron and Amir Ziv. 2001. "Dividend Changes and Future Profitability." The Journal of Finance, Vol. LVI, No. 6: 2111-2133.

30. Sung, Taeyoon, Daehwan Kim, and Ludwig Chincarini. 2006. "Corporate Scandals and the Market Response of Dividend Payout Changes." Applied Financial Economics, Vol. 16: 535-549.

31. Tong, Yen H. and Bin Miao. 2011. "Are Dividends Associated with the Quality of Earnings?" Accounting Horizons, Vol. 25, No. 1: 183-205.

32. Wann, Christi and D. Michael Long. 2008. "Do Liquidity Induced Changes in Aggregate Dividends Signal Aggregate Future Earnings Growth?” Journal of Economics and Finance, Vol. 33: 1-12. 